\title{
Rodna kuća Ivana Mažuranića u Novom Vinodolskom*
}

U prilogu se na temelju uvida u korespondenciju, katastarske izvore i drugo gradivo odgovara na pitanje gdje se nalazila rodna kuća Ivana Mažuranića u Novom Vinodolskom. Opovrgavaju se alternativne pretpostavke i potvrđuje da je „ban pučanin“ rođen u kući koju je njegov brat Matija 1864. proširio i nadogradio, a u kojoj se danas nalazi Dječji dom „Braća Mažuranići“.

\section{Uvod}

O Ivanu Mažuraniću, hrvatskom književniku i političaru, glasovitom „banu pučaninu“ i građanskom reformatoru, mnogo se toga zna ili je već istraženo i napisano. Među ostalim, poznato je da je rođen u nekadašnjem komorskom kaštelu Novom u Vinodolu (danas Novi Vinodolski) 11. kolovoza 1814., u skromnoj težačkoj obitelji novljanskog slobodnjaka Ivana (Mikule) Mažuranića Petrova i njegove žene Marije Kate, rođ. Ivić. ${ }^{1}$ Smatra se da je došao na svijet u kući koju je 1864. proširio i nadogradio njegov brat Matija Mažuranić na katastarskoj čestici (k. č.) 3602 u predjelu Šćedine, nedaleko od stare frankopanske kule zvane „kvadrac“. Danas je to četvrt u središtu Novog Vinodolskog, no u vrijeme rođenja Ivana Mažuranića taj je dio pripadao seoskoj okolici izvan granica komorskog kaštela Novi, iako se prostirao u njegovoj neposrednoj blizini. Na toj čestici nalazi se danas kuća br. 549 s dvorištem, ukupne površine 251 četvorni hvat (čhv.), koja se nalazi u vlasništvu Grada Novog Vinodolskog. Na kući je prije više od pola stoljeća postavljena spomen-ploča sljedećeg sadržaja:

$$
\begin{aligned}
& \text { „U ovoj nekad seljačkoj kući } \\
& \text { Rodiše se književnici } \\
& \text { I prvoborci narodnog jedinstva } \\
& \text { ANTUN MAŽURANIĆ }
\end{aligned}
$$

\footnotetext{
* Članak je nastao na poticaj gosp. Bojana Zoričića iz Novog Vinodolskog, kojem zahvaljujem na ustupljenim materijalima i konstruktivnoj suradnji u obostranoj želji za znanstvenim utvrđivanjem vjerodostojnih činjenica.

1 ŽIVANČEVIĆ 1988: 16.
} 
Profesor i slavist 1805.-1888.

IVAN MAŽURANIĆ

Pjesnik 1814.-1890.

MATIJA MAŽURANIĆ

Putopisac 1817.-1881.

VLADIMIR FRAN MAŽURANIĆ

Književnik 1859.-1928.

Godine 1864. proširiše i nadogradiše

Očevu seljačku kuću

Te postaviše čelo kuće natpis

BRATJA MAŽURANIĆI

1864.

Nije visok, tko na visu stoji,

Nit je velik, tko se velik rodi,

Već je visok, tko u nizu stoji,

I visinom nadmaša visine,

A velik je, tko se malen rodi,

Al kad pane golem grob mu treba.

(I.M. JAVOR - 1839.)

Ovaj spomen postaviše

NOVLJANI 1955.“

Manje je poznato da je Odbor za proslavu stogodišnjice rođenja Ivana Mažuranića u Novom, u suradnji s Družbom „Braća Hrvatskoga Zmaja“ iz Zagreba, namjeravao još 15. kolovoza 1914. otkriti spomen-ploču braći Mažuranićima na toj kući. „Spomen-ploču, koja će se shodnosti radi otkriti na rodnoj im kući dana 15. kolovoza 1914. o. g. u 11 sati prije podne, izradio je kipar g. Vatroslav Drenski, a otkrit će ju braća Hrvatskog Zmaja iz Zagreba“, najavio je spomenuti Odbor u srpnju 1914., ali je svečanost zbog izbijanja Prvoga svjetskog rata odgođena na neizvjesno vrijeme. ${ }^{2}$ Tada je rodna kuća braće Mažuranića bila u vlasništvu potomaka novljanskog bilježnika Ladislava Potočnjaka koji se oženio s Marijom, kćerkom Matije Mažuranića. Nasljednici su prodali kuću Hrvatsko-slavonskodalmatinskoj zemaljskoj vladi koja je u nju smjestila novljansku Građansku školu, a danas se u njezinim prostorijama nalazi Dječji dom „Braća Mažuranići“.

Budući da Status animarum („Stališ duša“) rimokatoličke župe Novi iz prve polovine 19. stoljeća, dostupan na digitalnoj snimci u Hrvatskom državnom arhivu (HDA) u Zagrebu, jasno razlikuje nekoliko obiteljskih grana Mažuranića ${ }^{3}$, kako je vrijeme prolazilo, tako su se pojavile dvije alternativne pretpostavke o tome gdje se nalazila rodna kuća Ivana Mažuranića: 1. „Dvorac“ u blizini župnog dvora iz 18. stoljeća na k. č. 233 u Novom i 2. Petrinovićeva kuća u Ulici Dušana Šebalje

$2 \quad$ Hrvatska prosvjeta, god. I, br. 8, Zagreb, kolovoz 1914., 407.

3 HDA, Zagreb, Status animarum Župe Novi Vinodolski (1808. - 1839.). 
6 na k. č. 3384 u Šćedinama. Prvu pretpostavku promovirao je srpski pedagog i pedagoški pisac Milan Šević još 14. listopada 1931. u članku „U kojoj se kući rodio Ivan Mažuranić?"“ u beogradskoj Politici ${ }^{4}$, što je problematizirao hrvatski književni povjesničar i sportski djelatnik Franjo Bučar 1. siječnja 1932. u članku „Gdje se rodio ban i pjesnik Ivan Mažuranić?" u zagrebačkom Jutarnjem listu. ${ }^{5}$ Drugu pretpostavku popularizirao je Dragomir Babić, sveučilišni profesor iz Rijeke i ljubitelj novljanskih starina, u listopadu 1989. u članku „Traganje za novljanskom dimenzijom“, objavljenom ususret 100. obljetnici smrti Ivana Mažuranića u crikveničkom Primorskom vjesniku. ${ }^{6}$ Alternativne pretpostavke nisu se nikada nametnule kao dominantan diskurs u pristupu toj problematici, ali kako su one potencijalno žarište sumnji i nesporazuma, potrebno je u kritičkom traganju za autentičnom prošlom stvarnošću najprije posegnuti za mjerodavnim izvorima.

\section{Što govore izvori?}

Za razrješenje nedoumica oko stvarne rodne kuće Ivana Mažuranića vrlo su korisna pisma Matije Mažuranića bratu Antunu, koja je još 1953. objavio književni povjesničar Ivan Brlić.7 Za problematiku rodne kuće važno je i pismo, odnosno prvi dio pisma koje se čuva među korespondencijom u sklopu rukopisne ostavštine Matije Mažuranića u Zbirci rijetkosti Nacionalne i sveučilišne knjižnice (NSK) u Zagrebu. Riječ je o pismu koje je Matija, nakon povratka iz Bosne, 8. prosinca 1853. iz Novoga poslao braći Ivanu i Antunu u Zagrebu:

„Ja sam došao u Novi još na 20. studenog, gdie sam naše živuće rodjake i priatelje našao u dobrom zdravju.

Ja sam se $\mathrm{s}$ bratom Josipom pogodio i načinio, premda ne baš u najliepšemu miru. - Meni je ostao kovački alat (ono što se već nije podieliti moglo) za 50 fl., a Josipu lanbik za $30 \mathrm{fl}$. - On je pripoznao pogrebni trošak pok. otca i dug Bužićki kako se je i prie bio očitovao, što no smo mi dva medju se razdielili.

Budući da je meni pok. otac dao $68 \mathrm{fl}$. da konja kupim kojeg sam i kupio, zato smo je izbrisali. A za onih 14 fl. 18 kr. koje je pok. otac potrošio na Marijinu kuću i livadu, piše u istoj knjižici 'a ja sam prijel od Marijina fita 15 fl.' zato smo i te odbacili.

Po isti način i ja što sam otcu dao 153 fl. odbacio sam; sada samo još ostaje što je pokojni primio u odsutstvu momu $130 \mathrm{fl} .10 \mathrm{1} / 2 \mathrm{kr}$. a to Josip neće da prizna. - U ostalom ja bi imao njemu dati od vina od alata i od niekog računa što je on

\footnotetext{
$4 \quad$ Politika, god. XXVIII, br. 8416, Beograd, 14. oktobra 1931., 9.

5 Jutarnji list, god. XXI, br. 7153, Zagreb, 1. siječnja 1932., 20-21.

6 Primorski vjesnik, br. 29, Crikvenica, listopad 1989., 9-10.

7 Vidi BRLIĆ 1953: 109-169.
} 
potrošio na Marijinom stožišću svega skupa 65 fl. za koje sam mu rekao čekati dok od Vas pismo dojde“. 8

Iz citiranog dijela pisma proizlazi da se Matija nagodio s bratom Josipom, doduše, ne bez nesuglasica, tako da je zadržao kovački alat i definirao neke troškove. Predmet diobe tom prilikom nije bila nijedna kuća, utoliko prije što je njihov otac Ivan Petrov ,još za života svoga nama na razdiljenje ustupio“" obiteljske nekretnine, kako stoji u Matijinu pismu bratu Antunu iz Novoga 13. kolovoza 1856. godine. ${ }^{9}$ Jedina kuća koja se u pismu od 8. prosinca 1853. spominje jest tzv. Marijina kuća u Šćedinama, zapravo kuća Matijine žene Marije, rođ. Kabalin, koja se povremeno spominje i u drugim pismima.

U rukopisnoj ostavštini Antuna Mažuranića u Zbirci rijetkosti zagrebačke Nacionalne i sveučilišne knjižnice sačuvano je još jedno važno pismo koje je Antun u Zagrebu 2. ožujka 1853. napisao bratu Josipu i „,snahi“, zapravo šogorici Mariji, Matijinoj ženi u Novom, odgovarajući na pisma koja su oni poslali iz Novoga 10. i 23. veljače 1853. braći Antunu i Ivanu u Zagreb. U pismu se spominje smrt banova oca Ivana Petrova i iznosi prijedlog za razdiobu jednog dijela novljanske baštine:

„Dragi brate Josipe i snaho Mario!

Primio sam tvoj list Josipe od 10. Veljače, u kojem si nam javio, da nam je otac pogibelno bolestan. Ja bih bio onda odmah tamo došao, da svoga miloga roditelja pohodim, ali sam bio službeno zaprěčen, buduć da smo imali školne izpite sve od 10. veljače do danas. Ivana pako nije bilo u Zagrebu, i tako nismo mogli dojti nijedan.

Tvoje pismo od 23. Veljače, kojim si nam javio směrt otčinu, bacilo nas je u veliku žalost, a mene tim većma, što sam u njem izgubio ne samo ljubljenoga otca nego i najboljega svoga prijatelja na světu. Milo mi je medjutim razuměti, da je pokojnik tako hrabro pretèrpio poslědnje muke, da se nije hotio ni potužiti. Bog mu daj pokoj věčni!

Ti i Maria pitate mene i Ivana, 1) što ćemo od ove zemlje, koja je nam u dio spala; zatim 2) što mislimo o kućah, zemljah i pokućtvu, koje je pokojnik za sebe bio zaderžao; pak 3) kako bi se imala poděliti marva i lětina; i najposlě 4) što ću ja sa svojimi Solinami.

Ja i Ivan dogovorili smo se danas o tom, pak želeći da se nezapusti zemlja, odlučili smo na svako pitanje što slědi:

1. Ivanov dio zemlje da obdělavaš i deržiš ti Josipe, kakovo si i dosad; a moj dio da radi i dèrži Maria kakovo je i dosad.

2. Pokojnikova ostavština sastojeća u kućah s pokućstvom pak u zemljah: Poludinku, Jadru i Solnik; onda u Šćedinah stožišću i ogradji; poslie u vèrtu

$8 \quad$ NSK, Zagreb, Zbirka (rijetkih) rukopisa i starih knjiga, R 5838 Mažuranić Matija, Rukopisna ostavština. Lanbik ili lambik je kotao za pečenje rakije.

9 BRLIĆ 1953: 158. 
Bočki; u livadah Karlovcu i Kèrču i napokon u velikom lugu u Lurini, da se odmah sada za stalno neděli, nego da vas dvojica, Ti i Marija lětos privrěmeno podelite samo zemlje medju se, pak da svaki svoju polovicu za sebe obradi. Napriliku ovako: jedan da dèrži Poludinak, Šćedinu stožišće, i Bočak; a drugi Jadro, Soline, Šćedina ogradju i livadu Karlovac. Lug pako u Lurinu i Kèrč da skupno dèržite, t. j. da u Lurinu pasete skupa, a Kèrč da pokosite skupa, pak da podělite sěno. Ili ako se vama obojici dopada za lětos drugačije poděliti, a vi učinite, kako se vam vidi: ako svakako je moja i Ivanova želja, da nebude medju vami nikakve svadnje ni nemira, da nam se drugi svět ne ruga. Što se pako tiče kućah s pokućstvom i raznim orudjen, mislimo nas dvojica, da ovoga nije tolika sila odmah děliti, nego je potrěbno, da se popiše sve pokućstvo, i to da vi sami učinite, ti i još koi čověk od strane Marijine, pak kada bude popisano, da ostane još doněkle u rukah Marijinih. A ti ćeš kada ti bude lazno u sporazumljenju s Marijon načiniti predlog, kako bi se sva ta otčina ostavština mogla za stalno poděliti, i to pokućstvo i orudje na dvoje, a nepomična na četvero, pak ćeš nam to na pismu priobćiti, ter ćemo onda dokončati.

3. Što se tiče marve i lětine, nalazimo ja i Ivan, da se i to kao ostavština pokojnoga otca mora poděliti, a to konačno medju vas dvojicu na dvoje. $\mathrm{Nu}$ u tom vam mi dva težko možemo dati nauka, kako da dělite; jer niti poznamo tih volovah, ni kravah, ni konja; niti znamo, koliko ima te lětine i dali je s Marijinon poměšana ili ne. Mi zato mislimo, da marvu podělite prijateljskim načinom u miru kako najbolje znate sami, a što se tiče lětine, t. j. sěna, vina, žita, i žukve, u tom, ako vas dvojica složno ne volite drugačije, ravnajte se ovako:

a) najprije trěba viděti koliko je svega skupa vina prirodilo na svih zemljah, što je pokojni skupa s Marijom dèržao, t. j. i na pokojnikovoj zemlji, i na Marijinoj (ako je njezino bilo s otčinim směšano) i na mojoj, pak se onaj broj napiše, n. p. 50 spudih.

b) zatim trěba odbiti ono, što je do pokojnikove smèrti prodato ili potrošeno, kao recimo n. p. 10 spudih, pak bi ostalo 40 spudih.

c) onda treba iznajti, koliko je prošaste jeseni prirodilo vina na otčinoj zemlji Poludinku, Jadru i Malih solinah (a to se more znati polag broja měhih masta) pak se to napiše, n. p. ako je na rečenih tih komadih bilo 45 měhih, to je od prilike 15 spudih vina.

d) naposlě učini se račun ovako: Ako je od 50 spudih svega skupa směšanoga vina potrošeno ili prodato 10 spudih; koliko se je moralo potrošiti od 15 spudih, ter će se najti spuda 3, a ostajalo bi još vina što je na otčinoj zemlji prirodilo, 12 spudih, što bi vas dvojica, ti Josipe, i Maria medju sobom na dvoje imali poděliti. A ono drugo, što se morda nalazi, jest 
Marijino vino, koje zapade na děljenje, neka stoji skupa dok se proda, pak onda podělite novce.

Tako možete učiniti sa sěnom, žitom i žukvom.

Krumpir pako, kiselo zemlje i repu mislimo mi dva, da nebi bilo lěpo děliti, nego da bude Mariji.

4. Glede mojih Solinah napokon odgovaram: Ti, brate Joso, dobro znaš da sam ja Soline jedino zato kupio, da otcu učinim kakvu radost, i da ga sklonim, da što prije dopusti poděliti zemlje, i da dade tebi tvoj dio. Buduć pako, da je Marija bila najveća prigledalica i podpora otčina, mislim da bih sagrěšio proti pokojnomu otcu, kad nebih njoj dao ne samo lětinu koja je onde prirodila, ako još nije potrošena, nego i iste Soline na dèřanje do daljnjega mojega s njom sporazumljenja.

Ovaj list pročitaj Mariji od početka do kraja, ter gledajte da se što većma po njem ravnate. I ako bude Marija želěla, ostavi ga kod nje, da ga ona može dati još komu drugomu pročitati.

Ako Vam bude još štogod nejasno, nerazumivo ili težko u děljenju, moć ćemo se još pismeno razuměti, premda ja mislim da ću vas morda ovoga uskèrsa pohoditi.

Budite obadva zdravi; a Ti Josipe imaj dobrotu pak se potrudi do prečastnoga g. Žanića, ter mu izruči moj pozdrav.

Primio sam tvoje pismo i za natěčaj ostavštine pokojnoga Sriće. Ali pokojni Srića meni nije ništa ostao dužan; ja imam obligaciju od Tereze i mladoga Sriće Mikule.

Zagreb, 2/3 [1]853.“10

Iz citiranog pisma proizlazi da je Ivan Petrov, otac bana Ivana Mažuranića, umro neposredno prije 23. veljače 1853., kada je Josip napisao pismo kojim je braći Antunu i Ivanu u Zagrebu priopćio vijest o očevoj smrti. To se dosad nije sigurno znalo, pa se i u rodoslovlju Mažuranića obično navodi da je Ivan Petrov umro 22. veljače $1844 .{ }^{11}$ No, citirano pismo ne ostavlja nikakve sumnje da je 22 . veljače 1853. jedini mogući točan i ispravan datum smrti banova oca. U pismu se nadalje konstatira činjenica da su obiteljske nekretnine podijeljene još prije očeve smrti, što potvrđuje i Matijino pismo bratu Antunu od 13. kolovoza 1856., pri čemu je naročito važan spomen ostavštine koja se sastojala „u kućah s pokućstvom pak u zemljah“ koje je „pokojnik za sebe bio zaderžao“. Podjela te imovine, prema onome što se navodi u pismu, odgođena je do daljnjega, napose kad se radilo o kućama. Odgođen je bio i gruntovni prijepis kako dotične, tako i ostale obiteljske imovine na imena nasljednika, s obzirom na to da Matija u spomenutom pismu

$\overline{10}$ NSK, Zagreb, Zbirka (rijetkih) rukopisa i starih knjiga, R 5840 Mažuranić Antun, Rukopisna ostavština. Spud ili vjedro je stara mjera za tekućine, osobito vino. Vrijednost mu se, ovisno o veličini (malo, srednje, veliko), kretala od 26 do 56 litara.

11 ŽIVANČEVIĆ 1979: 641. 
bratu Antunu od 13. kolovoza 1856. piše kako „naše nepokretnosti jesu još sve na pokojnoga otca upisane“. ${ }^{12}$

Sljedeći kronološki važan trag, zapravo najvažniji, jest Zapisnik Dielčićah/ Parzellen Protocol katastarske općine (k. o.) Novi iz 1860., koji se čuva u Arhivu mapa za Hrvatsku i Slavoniju u Hrvatskom državnom arhivu u Zagrebu. $\mathrm{Na}$ temelju tog upisnika čestica izrađen je 1861. katastarski plan k. o. Novi u 28 listova, čija se kopija čuva u istom arhivu. Taj je plan povijesna osnova današnjeg plana k. o. Novi. Uvidom u navedeni upisnik čestica mogu se identificirati kuće, gospodarske zgrade i dvorišta u Novom i Šćedinama, odnosno nekretnine koje su tada bile upisane na potomke Ivana Mažuranića Petrova te pojedine njihove susjede u gradu i okolici (Nikodem Dobrić Antonov, Anton Šebalja Antonov), a koje su od neposredne važnosti u traganju za lokacijom banove rodne kuće, pri čemu se povijesno stanje iz 1860. može uspoređivati s današnjim podacima iz mrežnih preglednika zemljišnih knjiga k. o. Novi. ${ }^{13}$

U upisniku čestica iz 1860. u gradu Novom upisana je na k. č. 3 gospodarstvena zgrada na površini od 11 čhv. u vlasništvu Matije Mažuranića, kbr. 404. Prema današnjem zemljišno-knjiškom (z. k.) izvatku, to je gospodarska zgrada „na Plasi“ (zapravo na „placi“, odnosno pijaci ili trgu) u Novom u vlasništvu Grada Novog Vinodolskog. Nedaleko su od te čestice k. č. 7 i 8: na njima su 1860. bili kuća br. 145 na površini od 11 čhv. te dvorište površine 3 čhv. u vlasništvu Antona Šebalje Antonova i suvlasništvu Antona Zoričića Jurija, kbr. 144. Danas se na k. č. 7 nalazi kuća br. 196 na pijaci u Novom, upisana na Osmana Omera, Krmpotska 15, a na k. č. 8 ,shod pred kućami“ u Novom, upisan na Sinišu Domića iz Zagreba. U susjedstvu je k. č. 10: to je 1860. bilo dvorište površine 6 čhv. u vlasništvu Antona Šebalje Antonova, kbr. 145, te suvlasništvu Antona Zoričića Jurija, kbr. 144, i Jele Zoričić. Danas ne postoji z. k. uložak za tu česticu, iz čega se može zaključiti da je pripojena drugoj čestici. Slijedi k. č. 12: to je 1860. bilo dvorište površine 7 čhv. u vlasništvu Antuna Ivića i Ivana Josipova, kbr. 139, i suvlasništvu Josipa Mažuranića Ivanova, kbr. 142. Danas je to „dvorište kod kuće“ u Novom, upisano na Vlastu Nižetić, Korzo hrvatskih branitelja 17. Posebno je interesantna k. č. 13: to je 1860. bila kuća br. 142 na površini od 10 čhv. u vlasništvu Josipa Mažuranića Ivanova. Danas je to kuća upisana na Vlastu Nižetić, N. Fronta 5. Odmah do nje nalazi se k. č. 17: to je 1860. bila kuća br. 148 s dvorištem površine 92 čhv. u vlasništvu Nikodema Dobrića Antonova. Danas je to kuća br. 200 „i dvor" površine 88 čhv., upisana na Osmana Omera, Krmpotska 15. ${ }^{14}$

\footnotetext{
$12 \quad$ BRLIĆ 1953: 158.

13 HDA, Zagreb, Arhiv mapa za Hrvatsku i Slavoniju, kut. 104. Također: http://e-izvadak.pravosudje.hr/pretraga-zk-ulozaka.htm (osnovni pristup ostvaren 23. rujna 2015., a kontrolni 20. srpnja 2016.).

14 Isto.
} 
Sljedeća je po važnosti za našu temu u gradu Novom, prema upisniku čestica iz 1860., k. č. 79: to je 1860. bilo dvorište površine 25 čhv. u vlasništvu Matije Mažuranića Ivanova, kbr. 209, i suvlasništvu Josipa Sokolića Jurjeva, kbr. 5, koji su to dvorište kupili od Matije Maričića, kbr. 202, Ivana Sokolića Mateova, kbr. 209, i Mate Sokolića Jurjeva, kbr. 210. Danas je to „dvorište kod kuće“ u Novom, upisano na troje vlasnika (Ivan Mažuranić s prebivalištem u Švedskoj, Milica Mažuranić s prebivalištem u Švicarskoj i Ivana Miković s prebivalištem u Zagrebu). U blizini je k. č. 82: to je 1860. bila kuća br. 209 na površini od 14 čhv. u vlasništvu Matije Mažuranića Ivanova koji je tu kuću kupio od Ivana Sokolića Mateova. Danas je to kuća br. 287 „, i dvor“, upisana na Ivana Mažuranića s prebivalištem u Švedskoj i Milicu Mažuranić s prebivalištem u Švicarskoj. Slijedi k. č. 98: to je 1860. bila kuća br. 213 s gospodarstvenim zgradama i dvorištem površine 36 čhv. u vlasništvu Matije Mažuranića Ivanova koji je tu imovinu stekao kupovinom od Grge Sokolića Grgina. Danas je to kuća br. 291 „i dvor“, upisana također na spomenutog Ivana Mažuranića s prebivalištem u Švedskoj i Milicu Mažuranić s prebivalištem u Švicarskoj..$^{15}$ Ivan i Milica, današnji vlasnici na k. č. 82 i 98 i suvlasnici na k. č. 79, unuci su Milutina Mažuranića koji je po majci Anki unuk Matije Mažuranića.

U upisniku čestica iz 1860. u gradu Novom na k. č. 233 upisana je kuća br. 261 na površini od 5 čhv. u vlasništvu Filipa Mažuranića Frankova. To je „Dvorac“, kućica u kojoj je, prema mišljenju nekih, na svijet došao ban Ivan Mažuranić, ali treba imati na umu da je Filip Mažuranić Frankov pripadao drugoj obiteljskoj grani Mažuranića, što je jasan pokazatelj da to nikako nije mogla biti banova rodna kuća. Danas je to kuća br. 353 „u Dvorcu“ na površini od 9 čhv., upisana na Ivanu Sokolić-Uršić Rozalijinu i Vjenceslavu Sokolić Rozalijinu, Šenoina 3. U obzir treba uzeti i k. č. 500: to je 1860. bila kuća br. 37 na površini od 8 čhv. u vlasništvu Grge Sokolića Grgina koji je tu kuću kupio od Matije Mažuranića Ivanova. Danas je to kuća br. 56 „na Malih vratih“ u Novom, upisana zajedno s kućom br. 413/52 na k. č. 501/1 površine 11 čhv. na Branku Pivac s prebivalištem u Rijeci, Boška Popovića s prebivalištem u Bjelovaru i Ivana Cindrića s prebivalištem u Lugu Samoborskom. U blizini je i k. č. 502: to je 1860. bilo dvorište površine 2 čhv. u vlasništvu Matije Mažuranića Ivanova, kbr. 404. Danas je to „svinjac kod kuće na Malih vratih“, koji ima čak sedmero vlasnika, čija su imena evidentirana u mrežnom pregledniku zemljišnih knjiga k. o. Novi. Spomenuti treba i k. č. 539: to je 1860. bila kuća br. 32 na površini od 16 čhv. u vlasništvu Josipa Mažuranića. Riječ je o kanoniku Josipu Mažuraniću, osnivaču novljanske čitaonice, pripadniku druge obiteljske grane Mažuranića. Danas je to kuća br. 49 u Novom, upisana na Vlastu i Irenu Šćurić iz Zagreba, s tim da na njoj stoji tablica s natpisom „Stari Grad 28“. ${ }^{16}$

\footnotetext{
15 Isto.

16 Isto.
} 
U upisniku čestica iz 1860. u Šćedinama upisana je na k. č. 3384 kuća br. 433 s gospodarstvenim zgradama i dvorištem površine 74 čhv. u vlasništvu Josipa Mažuranića Ivanova. Danas su to kuća br. 601 i „,dvorište u Šćedinah“, upisani na Jurja Petrinovića Pavlova, A. Mažuranića 62. U susjedstvu su, prema upisniku čestica iz 1860., bile k. č. 3379 (pašnjak površine 56 čhv. u vlasništvu Filipa Mrzljaka Petrova), k. č. 3380 (pašnjak površine 70 čhv. u vlasništvu Mande Piškulić), k. č. 3381 (pašnjak površine 80 čhv. u vlasništvu Lucije Piškulić), k. č. 3382 (pašnjak površine 40 čhv. u vlasništvu Josipa Peričića), k. č. 3383 (kuća br. 434 i gospodarstvene zgrade s dvorištem površine 30 čhv. u vlasništvu Luke Piškulića Pavlova, danas kuća br. 602 i dvorište u Šćedinama upisani na Jurja Petrinovića Pavlova, A. Mažuranića 62), k. č. 3385 (pašnjak površine 98 čhv. u vlasništvu Ivana Lindarića Matijeva), k. č. 3386/1 (oranica površine 61 čhv. u vlasništvu Petra Petrinovića Jurjeva koji je tu oranicu kupio od Ivana Lindarića Matijeva), k. č. 3386/2 (oranica površine 56 čhv. u vlasništvu Luke Petrinovića Jurjeva), k. č. 3386/3 (oranica površine 28 čhv. u vlasništvu Jurja Petrinovića Jurjeva) i k. č. 3386/4 (oranica površine 26 čhv. u vlasništvu Ivana Petrinovića Jurjeva). Preko puta su 1860. upisane k. č. 3464 (gospodarstvene zgrade na površini od 5 čhv. u vlasništvu Josipa Mažuranića Ivanova, kbr. 433) i k. č. 3465 (dvorište površine 9 čhv. u vlasništvu Ivana Lindarića Matijeva, kbr. 432, i suvlasništvu Josipa Mažuranića Ivanova, kbr. 433). U blizini je i k. č. 3496 (kuća br. 447 i gospodarstvene zgrade s dvorištem površine 31 čhv. u vlasništvu Ivana Sokolića Petrova koji je tu nekretninu kupio od Matije Mažuranića Ivanova). ${ }^{17}$

Upisnik čestica iz 1860. također bilježi u Šćedinama k. č. 3593 (vrt površine 95 čhv. u vlasništvu Matije Mažuranića Ivanova, kbr. 404), k. č. 3594 (gospodarstvene zgrade s dvorištem površine 82 čhv. u vlasništvu Matije Mažuranića Ivanova, kbr. 404), k. č. 3601 (dvorište površine 10 čhv. u suvlasništvu Matije Mažuranića Ivanova, kbr. 404, te suvlasništvu Antona Kriškovića Petrova, kbr. 406, i Marije Piškulić, kbr. 405) i k. č. 3602 (kuća br. 404 s dvama dvorištima i kuhinjskim vrtom površine 251 čhv. u vlasništvu Matije Mažuranića Ivanova). Danas je to kuća br. 549 s dvorištem u Novom, koja služi kao dječji dom, a zapravo je to kuća Matije Mažuranića i braće iz 1864., u čijem se dvorištu nalazi zdenac s uklesanom 1863. godinom, a na pročelju iznad glavnog ulaza piše: „1864. BRATJA MAŽURANIĆI“،.$^{18}$ Ona se u novljanskom žargonu naziva i Glavarovom kućom jer je Matija Mažuranić odlukom Riječke županije 1. svibnja 1856. imenovan „glavarom“ općine Novi i bio je posljednji novljanski glavar prije preustrojstva područne i lokalne uprave. ${ }^{19}$

\footnotetext{
17 Isto.

18 Isto.

19 BRLIĆ 1953: 158.
} 


\section{Analiza i interpretacija}

Što se iz navedenih podataka može ustanoviti? Prvo, upisnik čestica iz 1860. za Novi i Šćedine pokazuje da je Matija Mažuranić Ivanov bio upisan kao vlasnik kuće br. 404 s dvama dvorištima i kuhinjskim vrtom površine 251 čhv. na k. č. 3602. Imovinski spisi Matije Mažuranića u Zbirci rijetkosti Nacionalne i sveučilišne knjižnice u Zagrebu pokazuju da je vrt krasa na k. č. 3593 sudskim nalogom od 12. studenoga 1860. prenesen iz vlasništva vlastelina Ivana Maričića u vlasništvo Matije Mažuranića Ivanova. Ti spisi također pokazuju da je Matijinoj kući br. 404 na k. č. 3602 bila pridružena i staja, što može biti dio gospodarstvenih zgrada s dvorištem na k. č. $3594 .^{20}$ Kuću br. 209 na površini od 14 čhv. na k. č. 82 Matija je kupio od Ivana Sokolića Mateova, dok je kuću br. 213 i gospodarstvene zgrade s dvorištem površine 36 čhv. na k. č. 98 kupio od Grge Sokolića Grgina (kojem je zauzvrat prodao kuću br. 37 na površini od 8 čhv. na k. č. 500). Kuću i gospodarstvene zgrade s dvorištem na k. č. 3496 prodao je Ivanu Sokoliću Petrovu, a od njega je zauzvrat kupio gospodarstvene zgrade (među njima i staju) s dvorištem na k. č. 3594. ${ }^{21}$ Već je tada Matija bio upisan i kao vlasnik gospodarstvene zgrade na površini od 11 čhv. na k. č. 3 u gradu Novom.

Drugo, upisnik čestica iz 1860. za Novi i Šćedine pokazuje da je Matijin brat Josip Mažuranić Ivanov bio upisan kao vlasnik kuće br. 433 i gospodarstvenih zgrada s dvorištem ukupne površine 74 čhv. na k. č. 3384 u Šćedinama i kuće br. 142 ukupne površine 10 čhv. na k. č. 13 u Novom. Bio je također vlasnik gospodarstvenih zgrada na površini od 5 čhv. na k. č. 3464 u Šćedinama, suvlasnik dvorišta površine 9 čhv. na k. č. 3465 u Šćedinama i suvlasnik dvorišta na k. č. 12 u gradu Novom.

Matijina i Josipova braća Ivan i Antun živjeli su u Zagrebu. Imovinski spisi Ivana Mažuranića u Zbirci rijetkosti Nacionalne i sveučilišne knjižnice u Zagrebu pokazuju da je taj hrvatski političar i književnik još kao zagrebački državni nadodvjetnik, postavljen na tu dužnost u ožujku 1854., posjedovao 15 čestica urbarske zemlje (deset oranica, tri pašnjaka, jednu livadu i jedno neplodno zemljište) u Novom Vinodolskom, koju je stekao nasljeđem u obitelji Mažuranić. ${ }^{22}$ Katastarski posjedovni list br. 705 od 2. travnja 1878. pokazuje da je tadašnji „,ban pučanin“ posjedovao 16 čestica zemlje u Novom Vinodolskom ili jednu više nego u drugoj polovini 1850-ih godina, a i tada su to bile samo oranice, pašnjaci, livade i slično zemljište. Istodobno je banov brat Antun Mažuranić, gimnazijski ravnatelj u

\footnotetext{
20 NSK, Zagreb, Zbirka (rijetkih) rukopisa i starih knjiga, R 6425 Mažuranić Matija, Imovinski spisi.

21 Isto, R 5838 Mažuranić Matija, Rukopisna ostavština.

22 Isto, R 5851 Mažuranić Ivan, Imovinski spisi.
} 
Zagrebu, u rodnom Novom posjedovao samo tri zemljišne čestice, dok je drugi njegov brat Matija, koji je ostao živjeti u zavičaju, posjedovao čak 98 čestica, uključujući i kuću braće Mažuranića br. 404 na k. č. 3602. Kuće i zemlje četvrtog brata Josipa Mažuranića ne navode se u katastarskom posjedovnom listu br. 705 od 2. travnja 1878., što znači da su bile sasvim odijeljene od Matijine imovine i onoga što je pripadalo Ivanu i Antunu, s obzirom na to da je kuća braće Mažuranića br. 404 na k. č. 3602 tada bila upisana samo na Matijino, Ivanovo i Antunovo ime. ${ }^{23}$

Pisma i spisi koje je 1953. objavio Ivan Brlić pokazuju da je Ivan Mažuranić Petrov, banov otac, posjedovao obradivu zemlju i držao tuđe livade u zakupu, baveći se ratarstvom i stočarstvom. „Buduć da ov Kralj: Kameralski podložnik Ivan Mažuranić stanovnik u Novom; oratje zemlje po prilici dosta imade, a deržao je prvih godina tuje livade u zalogu kod sebe. Pokli jesu ove livade odkupljene, on ne ima na čemu deržati marhe; a prez nje ne može obdelavati zemlju, i česa radi već je skoro na skradnje siromaštvo opao", preporučivao je novljanski kaštelanat 2. rujna 1838. njegovu molbu komorskoj gospoštiji. ${ }^{24}$ Kupoprodajni ugovori i ostali imovinski spisi Ivana Mažuranića Petrova u Zbirci rijetkosti zagrebačke Nacionalne i sveučilišne knjižnice pokazuju da je taj komorski podložnik i novljanski slobodnjak tijekom života kupovao zemlju i postupno širio svoj posjed, iako je latentno bio na pragu siromaštva. Tako je u Novom 22. siječnja 1818. sklopljen kupoprodajni ugovor između Antona Ivića i Ivana Mažuranića Petrova o zemlji zvanoj „pod Pridolom“, kojim je Ivić prodao „vlašću zemlju zvanu pod Pridolom do czeste koja meisse ad istoka zemljum Andrija Ivica, a od termuntane zemljum Martina Maxuranicha, a to po mojoj sinovkyny sinovczu Ivanu Maxuranichu Petrovu za fiorinih treiset xtar 55. velim za no. 30 f. 55 xr. Zverhu koje zemlje Zapridola dajem Mojem sinovczu Ivanu Maxuranichu svu punu oblast i Gospodarstvo".25

U ostavštini Ivana i Vladimira Mažuranića u Arhivu Hrvatske akademije znanosti i umjetnosti (HAZU) u Zagrebu, među kupoprodajnim ugovorima, oporukama i drugim pravnim aktima iz Novoga u Vinodolu s kraja 18. i prve polovine 19. stoljeća, čuva se „Copia Delnoga Lista med dvimi Zeti Pokoinoga Ossipa Ivicha Ivanom Mazuranichiem, i Pavlom Zoricichiem, i Udovum Jellenum Pokoinoga Matia Toljana respective hchierum recenoga Pokoinoga Ossipa Ivicha“, načinjena 4. prosinca 1807. u komorskom kaštelu Novom, u kojoj se navodi: „Chasse pako dostoij kuchie Pokoinoga Ossipa Ivichia Tasta rechenich Zeet lezechie izvan Grada poli kuuch Sini Pokoinoga Mikule Zorichichia, ovu dva Zeta Mazuranich, i Zo-

23 NSK, Zagreb, Zbirka (rijetkih) rukopisa i starih knjiga, R 6425 Mažuranić Matija, Imovinski spisi.

24 BRLIĆ 1953: 131.

25 NSK, Zagreb, Zbirka (rijetkih) rukopisa i starih knjiga, R 5837 Mažuranić Ivan Petrov, Obiteljske isprave. 
richich, i Udova Jellena Matia Toljana jessu postavili na ochitu Muntu, koja Munta derzala jesse pod dnevom danasnijm va ovomu Kralievskomu Kastellu Kroz mene Zdola podpisanoga, na kojoi ochitoi Munti obechial je dati Zet Paval Zorichich Rainski Sest Sto, i pet, Za Koju Summu ostala jemu vikovicznim Zakonom kako najvechiemu Oblatoru, iliti Ponuditelju, od Koijh Rainski 605. imadati Passu Ivanu Mazuraniciu Rainski dvi Sto, i jedan Krajczari 40, velise fr. 201 xr. 40, a Udovi Jelleni Matia Toljana fr. 201 xr. 40, a na Pavla Zorichichia treti deel ostaju fr. 201 xr. 40. Summa Rainski fr. 605 xr. - " ${ }^{26}$ S druge strane, „Vikoviczno Pismo Ivana Mazuranicha Petrova na kuchiu izvan Grada lezechiu nijegova Pokojnoga Tasta Ossipa Ivicha, kuplienu na ochitoj Munti za Rainski 605“ forinti, održanoj također 4. prosinca 1807. u Novom, ,koja kuchia mejisse od burne Strane kuchium Antona Ivicha Ossipova, a od Juga Kuchium sini Pokoinoga Mikule Zorichichia“, pokazuje da je kuća poslije smrti Josipa Ivića Josipova, banova djeda s majčine strane, pripala Ivanu Mažuraniću Petrovu. ${ }^{27}$

Ostali sačuvani imovinski spisi banova oca ne sadrže podatke o njegovoj kući ili kućama, ali korespondencija koju je 1953. objavio Ivan Brlić i neka neobjavljena pisma iz ostavštine Antuna, Ivana i Matije Mažuranića svjedoče da se radilo o nekoliko kuća. Tako u pismu bratu Antunu iz Novoga 12. studenoga 1837. piše tada mladi kovački majstor Matija Mažuranić da je počeo kovati, ali da mu otac nije dao „va svojoj kući štuka delat“, nego je njemu i bratu Josipu rekao: „ami ako nećemo slušat neka idemo iz kuće“. Matija dalje piše da je zaista bio odlučio otići, ali „Mat su se plakali, i rekli su, da što će pak Osip i z'dicum! Neg da neka mi idemo skupa v’ duljnu kuću“ “. ${ }^{28}$ Ovdje se, dakle, spominju dvije kuće: glavna očeva i sporedna „duljna“ kuća. U pismu bratu Antunu iz Novoga na blagdan Tri kralja 1845. Matija piše da je „od Nikodeme Dobrića uzel na dil za 10 let ono dvorišće zada naše dolnje kuće pak ću u njemu napraviti kolariju i kovačiju“, a u pismu bratu Antunu iz Novoga 25. siječnja 1845. dodaje: „Toga dvora je malo više od 60 klaf. $\square$.“, tj. malo više od 60 čhv. U istome pismu Matija se usput bavi i „s’ našim susedom Šeboljum“, kojem je htio dati „kuću Marijinu u Šćedinah za onu kuću koja je s' našom u jednoj liniji““.29

Banov otac Ivan Mažuranić Petrov umro je 22. veljače 1853., podijelivši prije smrti svoju novljansku imovinu između sinova Matije i Josipa, ne računajući zemljišne čestice koje je ostavio Ivanu i Antunu, kao i neke kuće sa zemljom i pokućstvom koje je zadržao za sebe, kako proizlazi iz Antunova pisma iz Zagreba 2. ožujka 1853. bratu Josipu i šogorici Mariji. U pismu bratu Antunu iz Novoga 25. rujna 1854. Matija spominje „i kuću našu u Gradu“, a u pismu od 13. kolovoza 1856.

\footnotetext{
26 Arhiv HAZU, Zagreb, Ostavština Ivana i Vladimira Mažuranića, XV-43/I.3.

27 Isto, XV-43/I.4.

28 BRLIĆ 1953: 128.

29 Isto: $142-143$
} 
navodi ,da naše nepokretnosti jesu još sve na pokojnoga otca upisane, premda još za života svoga nama na razdiljenje ustupio biše, i u ista doba zemljarinskog popisa umro jest ${ }^{\text {" }}{ }^{30}$ Radilo se o carskom patentu o zemljišnom rasterećenju, potpisanom u Beču 2. ožujka 1853., kojim su ukinuti urbarski odnosi, nadležnost i vrhovno vlasništvo feudalnih gospoštija nad zemljama bivših seljačkih podložnika, pri čemu je država apsolutističkim reformama uvodila moderne posjedovne odnose $\mathrm{i}$ jamčila primjerenu naknadu bišvim svjetovnim i crkvenim posjednicima zemlje. Jedan od rezultata postupne likvidacije feudalizma, nakon što je ban Josip Jelačić 25. travnja 1848. ukinuo kmetstvo, bio je i spominjani upisnik čestica iz 1860. za k. o. Novi, nastao u sklopu sustavne franciscejske katastarske izmjere hrvatskih zemalja. ${ }^{31}$ Upisnik pokazuje da je Matija Mažuranić tada posjedovao kuću br. 404 s dvama dvorištima i kuhinjskim vrtom ukupne površine 251 čhv. na k. č. 3602 , dok je njegov brat Josip bio upisan kao vlasnik kuće br. 433 i gospodarstvenih zgrada s dvorištem ukupne površine 74 čhv. na k. č. 3384 u Šćedinama i kuće br. 142 na površini od 10 čhv. na k. č. 13 u Novom. Samo jedna od tih triju kuća, koje je pokojni Ivan Mažuranić Petrov ostavio sinovima Matiji (dobio je jednu kuću na velikoj čestici) i Josipu (dobio je dvije kuće na manjim česticama), mogla je biti rodna kuća bana Ivana Mažuranića. To nisu mogle biti kuće na k. č. 82 i 83 jer je njih Matija Mažuranić kupio od Ivana Sokolića Mateova i Grge Sokolića Grgina, a nije to mogao biti niti „Dvorac“" na k. č. 233, koji je, prema upisniku čestica iz 1860., pripadao drugoj obiteljskoj grani Mažuranića. Jednako tako, to nisu to mogle biti ni kuće na k. č. 500 i 3496, koje je Matija Mažuranić prodao Grgi Sokoliću Grginom i Ivanu Sokoliću Petrovu jer u tom slučaju Matijin sin Vladimir Fran Mažuranić ne bi mogao kasnije predviđati spomen-ploču na rodnoj kući Mažuranića, na kojoj je, prema sačuvanoj bilješci iz njegove pisane ostavštine $u$ Zbirci rijetkosti Nacionalne i sveučilišne knjižnice u Zagrebu, trebao biti tekst sljedećega sadržaja:

$$
\begin{aligned}
& \text { „U ovoj kući rodiše se } \\
& \text { hrvatski književnici } \\
& \text { Antun, Ivan i Mate } \\
& \text { Mažuranić } \\
& \text { i sin Matijev } \\
& \text { Vladimir - Fran“332 }
\end{aligned}
$$

Ako podatke iz upisnika čestica iz 1860. dovedemo u vezu sa spominjanjem glavne očeve i ,duljne“ kuće u Matijinu pismu bratu Antunu iz studenoga 1837. i spominjanjem uzimanja u zakup na 10 godina dvorišta Nikodema Dobrića

30 Isto: $155,158$.

31 Usp. SLUKAN ALTIĆ 2003: 302-307.

32 NSK, Zagreb, Zbirka (rijetkih) rukopisa i starih knjiga, R 6929 Mažuranić Fran, Razne bilješke. 
Antonova „zada naše doljne kuće“ površine „malo više od 60 klaf. $\square$.“ u pismu bratu Antunu iz siječnja 1845..$^{33}$, dolazimo do spoznaje da ta „duljna“ ili ,doljna“ kuća nikako nije mogla biti kuća br. 433 s gospodarstvenim zgradama i dvorištem površine 74 čhv. na k. č. 3384 u Šćedinama, upisana 1860. na Josipa Mažuranića Ivanova, iz dvaju razloga: 1.) k. č. 3384 na povišenom je brijegu i u odnosu na k. č. 3602 u Šćedinama i k. č. 13 u Novom, što znači da je ona iz perspektive tih dviju čestica prije „gore“ nego „dolje“ i 2.) niti jedna od katastarskih čestica u njezinu neposrednom susjedstvu nije bila 1860. upisana na Nikodema Dobrića Antonova, uključujući i k. č. 3386/1 odmah iza nje, ukupne površine 61 čhv. (što je najbliže površini dvorišta od „malo više od 60 klaf. $\square$ “"). Štoviše, k. č. 3386/1 nije uopće 1860. bila upisana kao „dvorište“ ili „,dvor“, nego kao „oranica“ koja je tada bila u rukama Petra Petrinovića Jurjeva, a ni prije toga nije bila u vlasništvu Nikodema Dobrića Antonova, nego je pripadala Ivanu Lindariću Matijevu (u upisniku čestica iz 1860. prekriženo je uz k. č. 3386/1 ime Ivana Lindarića Matijeva i iznad njega upisano ime Petra Petrinovića Jurjeva, što jasno pokazuje o kakvoj se promjeni vlasništva radilo).$^{34}$

Imamo li podatke iz upisnika čestica iz 1860. i dalje na umu, onda „duljna“ ili „doljna“ kuća iz Matijinih pisama bratu Antunu iz 1837. i 1845. nije mogla biti ni kuća br. 404 na k. č. 3602, koja je 1860. bila upisana na Matiju Mažuranića Ivanova, iako je ona s obzirom na konfiguraciju terena nedvojbeno „dolje“ u odnosu na spomenutu kuću br. 433 na k. č. 3384, upisanu 1860. na njegova brata Josipa Mažuranića Ivanova. Primarni je dokaz za to činjenica da upisnik čestica iz 1860. ni u neposrednom susjedstvu te kuće ne poznaje niti jednu česticu koja bi bila upisana na Nikodema Dobrića Antonova. Ako je tome tako, onda je „duljna“ ili ,doljna“ kuća mogla biti jedino i samo kuća br. 142 na k. č. 13 u gradu Novom, koja je 1860. bila u vlasništvu Josipa Mažuranića Ivanova, brata Matije Mažuranića (koji u nekim svojim pismima spominje ,i kuću našu u Gradu“). Odmah treba reći da je kuća br. 142 na k. č. 13 u Novom uistinu i bila „duljna“ ili „doljna“ kuća, upravo ona iza koje se prostiralo dvorište u kojem je Matija htio „napraviti kolariju i kovačiju“, jer katastarski plan iz 1861. nedvojbeno pokazuje da se odmah iza nje nalazila kuća br. 148 s dvorištem površine 92 čhv. na k. č. 17, koja je, prema upisniku čestica iz 1860., zaista bila u vlasništvu Nikodema Dobrića Antonova. Doduše, površina od 92 čhv. znatno je veća od površine od „,malo više od 60 klaf. $\square$ ๑“, ali to ništa bitno ne mijenja stvari jer je Nikodem Dobrić Antonov utoliko lakše mogao iznajmiti 60-ak čhv. dvorišta, koje je u novljanskom žargonu poznato kao „Carski dvor“" kad mu je na raspolaganju ostajalo još 30-ak čhv. dvorišta s kućom za vlastite potrebe. Osim toga, u pismu bratu Antunu iz Novoga 25. siječnja 1845.

BRLIĆ 1953: 128, 142.

34 HDA, Zagreb, Arhiv mapa za Hrvatsku i Slavoniju, kut. 104. 
Matija ne spominje samo to da je pogodio „s Dobrićem dvor na fit za 10 let“ $\mathrm{i}$ da „ovo dvorišće mora imati prihod od ceste ispod fratarskoga Dolca“ (danas je to Korzo hrvatskih branitelja), nego piše i da će ,svakako gledat okolo Ivića dami pusti svoju štalu“, a bavi se usput i „s našim susedom Šeboljum“, kojem je htio dati „kuću Marijinu u Šćedinah za onu kuću koja je s’ našom u jednoj liniji““.35 Upisnik čestica iz 1860. pokazuje da ni Anton Šebalja Antonov ni „Plovan Ivić“ nisu bili upisani kao vlasnici niti jedne čestice u neposrednom susjedstvu k. č. 3384 ili k. č. 3602 u Šćedinama, ali je zato Anton Šebalja Antonov bio upisan kao vlasnik kuće br. 145 na k. č. 7 i suvlasnik dvorišta na k. č. 8 u gradu Novom (prema katastarskom planu iz 1861., to je zaista u ,jednoj liniji“ s kućom na k. č. 13). Istodobno su Antun Ivić i Ivan Josipov bili upisani kao vlasnici dvorišta na k. č. 12 u Novom, s tim da je Josip Mažuranić Ivanov, vlasnik kuće na k. č. 13 u neposrednom susjedstvu, bio upisan kao suvlasnik toga dvorišta. ${ }^{36}$

Ako je kuća na k. č. 13 u Novom bila „duljna“ ili „doljna“, onda je u odnosu na nju glavna kuća starog Ivana Mažuranića Petrova, oca književnika i „bana pučanina“" Ivana Mažuranića, mogla biti samo kuća na k. č. 3602 ili ona na k. č. 3384 u Šćedinama. Na k. č. 3602 u upisniku čestica iz 1860. upisana je kuća br. 404 s dvama dvorištima i kuhinjskim vrtom na prostoru ukupne površine 251 čhv. u vlasništvu Matije Mažuranića, dok je na k. č. 3384 tada bila upisana kuća s gospodarstvenim zgradama i dvorištem na prostoru ukupne površine 74 čhv. u vlasništvu Josipa Mažuranića. Nije teško pretpostaviti da je kuća na čestici trostruko veće površine zacijelo morala glavna kuća banova oca, a time i banova rodna kuća. Na to dodatno upućuje i već citirano Matijino pismo bratu Antunu iz Novoga 12. studenoga 1837. godine: u njemu Matija pripovjeda kako mu otac, kao mladom kovaču, nije dao „va svojoj kući štuka delat“, nego je njemu i bratu Josipu rekao da „ako nećemo slušat neka idemo iz kuće“, što znači da su i Matija i Josip odrasli zajedno u očevoj kući. Matija u tome pismu nadalje prepričava što mu je otac tom prilikom još kazao: „Ja tebe dobre volje nisam dal u nauk, niti sam nigdar želel, da prideš doma. - Ali po svem tom kad si već prišal, ako ćeš ti udelat, što ja rečem, i u napridak vladat se po mojoj volji; ja ću te opet zet za mojega sina: A on (Osip) neka gre kamo mu drago" ${ }^{37}$ To pokazuje da Josip, iako stariji brat, nije mogao računati s tim da će dugoročno ostati u očevoj kući, što se i obistinilo prilikom podjele baštine. Nju je otac još za života razdijelio među sinovima, poglavito među onima koji su ostali živjeti u Novom Vinodolskom, učinivši to prilično ravnomjerno, s obzirom na to da su tada Josipu pripale dvije kuće na manjoj površini: naime, kuća s gospodarstve-

35 BRLIĆ 1953: 142-143.

36 HDA, Zagreb, Arhiv mapa za Hrvatsku i Slavoniju, kut. 104.

37 BRLIĆ 1953: 128. 
nim zgradama i dvorištem na k. č. 3384 u Šćedinama i ona na k. č. 13 u gradu Novom, dok je Matiji ostala jedna kuća na znatno većoj površini, tj. glavna kuća na k. č. 3602. Možda je i to razlog zašto je Josip negodovao kad su Ivan i Antun neke svoje zemlje prepustili na obradu Matijinoj ženi Mariji: „Naš brat Josip kada je došao iz Zagreba, nesamo da mi je došao javiti da ste darovali zemlju, nego poče kao za veći užas štarpnjati po kući, i dade mi darovni list u ruke da čitam. (...) To darovanje ružan je utisak učinilo u naših mieštanah jerbo Josip (: taj težak glasoviti :) i svoju pravu zemlju u nijednom redu darži, a Ivanova gotovo pusta ostaje“, kako piše Matija u pismu Antunu iz Novoga 25. rujna 1854. godine. ${ }^{38}$ Neke druge kuće zadržao je banov otac za sebe, kako pokazuje Antunovo pismo iz Zagreba 2. ožujka 1853. bratu Josipu i šogorici Mariji, a među njima su zacijelo bile i kuće koje su poslije očeve smrti također pripale Matiji i koje je Matija kasnije dijelom prodao Sokolićima i drugim novljanskim obiteljima, ne računajući kuće koje je od njih kupio.

Na to da je upravo kuća na k. č. 3602 bila glavna kuća obitelji starog Ivana Mažuranića Petrova i prije nego što ju je njegov sin Matija - koji se za života okušao i kao kovač i kao građevinski poduzetnik i kao pisac putopisa Pogled $u$ Bosnu iz 1839. - dao srušiti i na njenim temeljima 1864. podignuti novu kuću za sebe i svoju braću Ivana i Antuna (ne i Josipa koji je podjelom očevine dobio dvije kuće!), iskopavši godinu dana ranije zdenac u dvorištu, upućuje ne samo velika površina k. č. 3602 prema upisniku iz 1860., nego i svjedočanstvo Matijina sina Vladimira Frana Mažuranića u autobiografskom romanu Od zore do mraka, objavljenom 1927. u nakladi Matice hrvatske u Zagrebu. U njemu Fran piše: „Ta naša kuća bila je lijepa i ugledna jednokatna zidanica. Šteta, što su je porušili! (...) Moj je otac rušio kuću, da veću sazida, jer je mislio, da će se braća njegova pod starost preseliti u Novi. U staroj kući proživio sam prve četiri godine, pa je dobro pamtim. (...) Imali smo i konja i kočiju. (...) Konj i staromodna kočija, s kožnatim krovom, stajali su u štali. (...) Prije negoli zidaše kuću, morao se u dvorištu iskopati studenac, a u živcu kamenu. (...) Nisu porušili svega: sjeverni dio stare kuće ugrađen je u novu, tako da je kuća samo dograđena. (...) Bile su mi kakove četiri godine, kad se preselismo u novu kuću. Ta naša dvokatnica imala je 14 soba, a kako očeva braća volješe ostajati u Zagrebu, imali smo u njoj i suviše prostora““. ${ }^{39} \mathrm{O}$ zidanju dvokatnice na temeljima jednokatnice govori ponešto $\mathrm{i}$ prva rečenica iz ranije nepoznatog pisma Ivana Mažuranića iz Beča 23. veljače 1866. bratu Antunu: „Pisao mi je Matij da odmah isplatim f. 250, što je moj dug za troškove za gradnju naše kuće u Šćedinah". ${ }^{40}$

\footnotetext{
$38 \quad$ Isto: 154.

39 MAŽURANIĆ 1927: 21-25, 30-32.

40 Novljanski list, god. II, br. 7, Novi Vinodolski, kolovoz 2013., 10.
} 
Ako je kuća na k. č. 3602 u Šćedinama bila glavna kuća oca bana Ivana Mažuranića, a prikupljeni i izneseni podaci bjelodano ukazuju na to, onda jedino ona može biti banova rodna kuća! To nije mogao biti „Dvorac“ na k. č. 233 u Novom, s obzirom na to da je ta kućica pripadala drugoj obiteljskoj grani Mažuranića, a s njima ,smo se rijetko kada vidjeli“", kako u citiranom romanu Od zore do mraka tvrdi Fran Mažuranić. ${ }^{41}$ To ne može biti ni kuća na k. č. 3384 u Šćedinama: pogledom s lokacije kuće na k. č. 3384, kuća na k. č. 3602 doista jest ona koja je fizički „dolje“, ali upisnik čestica iz 1860. s preciznim podacima o susjednim kućama i dvorištima u vlasništvu Nikodema Antona Dobrića i Antona Šebalje Antonova ne ostavlja ni najmanje sumnje da je „duljna“ kuća iz pisma Matije Mažuranića bratu Antunu iz 1837. bila zapravo kuća na k. č. 13 u gradu Novom. Ako je tome tako, a podaci i dokazi ne ostavljaju mjesta dvojbama, onda je glavna očeva kuća mogla biti samo prva kuća iznad ove na k. č. 13 u gradu Novom, a to onda opet može biti samo kuća na k. č. 3602 u Šćedinama. Uostalom, Josipov sin iz drugog braka, Dragutin, prodao je kuću na k. č. 3384 ugovorom od 21. siječnja 1905. obitelji Petrinović, koja je, prema upisniku iz 1860., posjedovala pojedine čestice u neposrednom susjedstvu. Teoretski se „ban pučanin“ mogao roditi i u toj kući, ali to je s obzirom na sve pokazatelje uistinu malo vjerojatno. Da je tome zaista bilo tako, odnosno da rodna kuća braće Mažuranića kojim slučajem nije bila kuća na k. č. 3602 (poslije Građanska škola, a danas Dječji dom), teško bi Vladimir Fran Mažuranić kao izravni potomak mogao kasnije predviđati spomen-ploču za rodnu kuću braće Mažuranića i u prigodno zamišljenom tekstu, sačuvanom među njegovim bilješkama u Zbirci rijetkosti zagrebačke Nacionalne i sveučilišne knjižnice, izrijekom tvrditi da su i njegov otac Matija i njegovi stričevi Antun i Ivan kao hrvatski književnici rođeni u istoj kući u kojoj je poslije njih rođen i on:

\author{
„U ovoj kući rodiše se \\ hrvatski književnici \\ Antun, Ivan i Mate \\ Mažuranić \\ i sin Matijev \\ Vladimir - Fran“442
}

41 MAŽURANIĆ 1927: 35.

42 NSK, Zagreb, Zbirka (rijetkih) rukopisa i starih knjiga, R 6929 Mažuranić Fran, Razne bilješke. 


\section{Zaključak}

Hrvatski književnik i „ban pučanin“ Ivan Mažuranić došao je na svijet 11. kolovoza 1814. kao sin Ivana Mažuranića Petrova i majke Marije Kate, rođ. Ivić, u kući na k. č. 3602 u Šćedinama koje pripadaju k. o. Novi u Vinodolu (danas Novi Vinodolski). To je bila zidana jednokatnica prije nego što ju je njegov brat Matija, kao izravni nasljednik, djelomično porušio i na njenim temeljima 1864. sagradio zidanu dvokatnicu, ugradivši sjeverni dio stare kuće u novu. Proširena i dograđena kuća bila je 1878. upisana na njegovo, Ivanovo i Antunovo ime jer su braća Mažuranići dijelili taj dom, iako su Ivan i Antun zapravo živjeli u Zagrebu, gdje je Ivan i umro 4. kolovoza 1890., pa je u kući s 14 soba u Novome stanovao samo Matija koji je sa svojom obitelji ostao u zavičaju. U vrijeme stogodišnjice rođenja Ivana Mažuranića, čija je proslava u kolovozu 1914. izostala zbog izbijanja Prvoga svjetskog rata, kuća je bila u vlasništvu potomaka novljanskog bilježnika Ladislava Potočnjaka koji je oženio Mariju, kćerku Matije Mažuranića. Nasljednici su prodali kuću Hrvatsko-slavonsko-dalmatinskoj zemaljskoj vladi koja je u nju smjestila novljansku Građansku školu, a danas se u njezinim prostorijama nalazi Dječji dom „Braća Mažuranići“ u vlasništvu Grada Novog Vinodolskog. Kuće na k. č. 3384 u Šćedinama i k. č. 13 u gradu Novom pripale su podjelom očevine u drugoj polovini 1850-ih godina četvrtom bratu Josipu Mažuraniću, a ostale su kuće kasnije prodane Sokolićima i drugim novljanskim obiteljima ili su stečene kupovinom od njih. Josipov sin iz drugog braka, Dragutin, prodao je 1905. kuću na k. č. 3384 obitelji Petrinović, koja je, prema upisniku čestica iz 1860., posjedovala pojedine čestice u neposrednom susjedstvu. Kuća na k. č. 13 u Novom bila je upravo ona iza koje se prostiralo dvorište koje je Matija Mažuranić 1845. uzeo u zakup na deset godina od Nikodema Dobrića Antonova za potrebe kolarije i kovačije jer katastarski plan iz 1861. nedvojbeno pokazuje da se odmah iza te kuće nalazila kuća s dvorištem na k. č. 17, koja je, prema upisniku čestica iz 1860., bila u vlasništvu Nikodema Dobrića Antonova. „Dvorac“ na k. č. 233 u blizini župnog dvora iz 18. stoljeća u Novome nije mogao biti banova rodna kuća, s obzirom na to da je ta kućica 1860. bila u vlasništvu Filipa Mažuranića Frankova, pripadnika druge obiteljske grane Mažuranića, a s njima „smo se rijetko kada vidjeli“", kako je još 1927. u romanu Od zore do mraka posvjedočio Matijin sin Vladimir Fran Mažuranić. 
Bibliografija

Arhivsko gradivo

Arhiv Hrvatske akademije znanosti i umjetnosti, Zagreb

Ostavština Ivana i Vladimira Mažuranića.

Hrvatski državni arhiv, Zagreb

Arhiv mapa za Hrvatsku i Slavoniju, kut. 104.

Status animarum župe Novi Vinodolski (1808. - 1839.).

Nacionalna i sveučilišna knjižnica, Zagreb

Zbirka (rijetkih) rukopisa i starih knjiga: R 5837, R 5838, R 5840, R 5851, R 6425, R 6929.

\section{Objavljeni izvori}

BRLIĆ, Ivan. 1953. O braći Mažuranićima, Matiji i Ivanu [Građa za povijest književnosti hrvatske, knj. 24]. Zagreb: JAZU: 109-214.

MAŽURANIĆ, Fran. 1927. Od zore do mraka. Zagreb: Matica hrvatska.

ŽIVANČEVIĆ, Milorad. 1979. Ivan Mažuranić. Pisma, govori [Sabrana djela Ivana Mažuranića, sv. IV]. Zagreb: Sveučilišna naklada Liber, Nakladni zavod Matice hrvatske.

Novine i časopisi

Hrvatska prosvjeta, god. I, br. 8, Zagreb, kolovoz 1914.

Jutarnji list, god. XXI, br. 7153, Zagreb, 1. siječnja 1932.

Novljanski list, god. II, br. 7, Novi Vinodolski, kolovoz 2013.

Politika, god. XXVIII, br. 8416, Beograd, 14. oktobra 1931.

Primorski vjesnik, br. 29, Crikvenica, listopad 1989.

\section{Internet}

http://e-izvadak.pravosudje.hr/pretraga-zk-ulozaka.htm (posjet 20. 7. 2016).

\section{Literatura}

SLUKAN ALTIĆ, Mirela. 2003. Povijesna kartografija. Kartografski izvori u povijesnim znanostima. Samobor: Meridijani.

ŽIVANČEVIĆ, Milorad. 1988. Ivan Mažuranić. Novi Sad-Zagreb: Matica srpska, Globus. 


\section{The Birthplace of Ivan Mažuranić in Novi Vinodolski}

Based on the correspondence, cadastral and other sources, this article is an attempt to resolve the issue of the location of the birthplace of Ivan Mažuranić, nineteenth-century Croatian writer and ban (viceroy), in the town of Novi Vinodo1ski on the Northern Adriatic coast. There are three assumptions about Mažuranić's birthplace: 1) the house of the Mažuranić brothers on the cadastral plot no. 3602 in the town district of Śćedine; 2) the so-called "Castle" near the eighteenth-century parish house on the cadastral plot no. 233 in the town centre, and 3) the Petrinović house located at the Street of Dušan Šebalja 6 on the cadastral plot no. 3384 in the other part of the Šćedine town district. Disproving alternative assumptions, the analysis confirmed that Ivan Mažuranić was born in the house on the cadastral plot no. 3602 in the town district of Šćedine in Novi Vinodolski, which was enlarged and extended by his brother Matija Mažuranić in 1864, and which today houses the "Braća Mažuranići" (Brothers Mažuranić) Children's Home.

Keywords: Ivan Mažuranić, Novi Vinodolski, birthplace.

Ključne riječi: Ivan Mažuranić, Novi Vinodolski, rodna kuća.

Željko Holjevac Filozofski fakultet Sveučilišta u Zagrebu HR-10000 Zagreb, Ivana Lučića 3 zeljko.holjevac@gmail.com 


\section{FILOZOFSKI FAKULTET SVEUČILIŠTA U ZAGREBU \\ ZAVOD ZA HRVATSKU POVIJEST \\ INSTITUTE OF CROATIAN HISTORY \\ INSTITUT FÜR KROATISCHE GESCHICHTE}

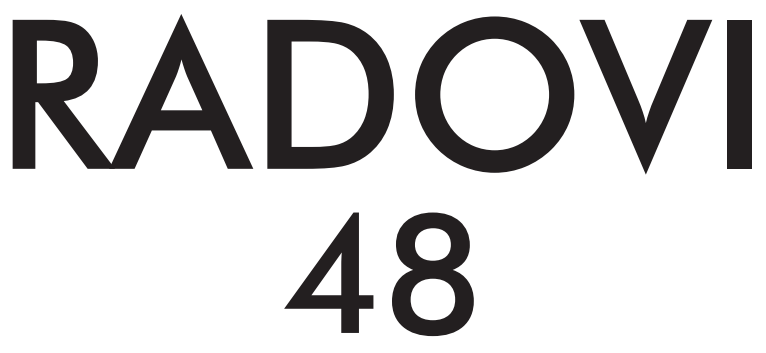

ZAVOD ZA HRVATSKU POVIJEST

FILOZOFSKOGA FAKULTETA SVEUČILIŠTA U ZAGREBU

\section{FF press}

ZAGREB 2016. 


\title{
RADOVI ZAVODA ZA HRVATSKU POVIJEST FILOZOFSKOGA FAKULTETA SVEUČILIŠTA U ZAGREBU \\ Knjiga 48
}

\author{
Izdavač / Publisher \\ Zavod za hrvatsku povijest \\ Filozofskoga fakulteta Sveučilišta u Zagrebu \\ FF-press \\ Za izdavača / For Publisher \\ Željko Holjevac \\ Glavni urednik / Editor-in-Chief \\ Hrvoje Gračanin \\ Izvršna urednica / Executive Editor \\ Inga Vilogorac Brčić \\ Uredništvo / Editorial Board
}

Bruna Kuntić-Makvić (stara povijest/ancient history), Zrinka Nikolić Jakus (srednji vijek/ medieval history), Hrvoje Petrić (rani novi vijek/early modern history), Željko Holjevac (moderna povijest/modern history), Tvrtko Jakovina (suvremena povijest/contemporary history),

Silvija Pisk (mikrohistorija i zavičajna povijest/microhistory and local history),

Zrinka Blažević (teorija i metodologija povijesti/theory and methodology of history)

Međunarodno uredničko vijeće / International Editorial Council

Denis Alimov (Sankt Peterburg), Živko Andrijašević (Nikšić), Csaba Békés (Budapest), Rajko Bratož (Ljubljana), Snježana Buzov (Columbus, Ohio), Svetlozar Eldarov (Sofija), Toni Filiposki (Skopje), Aleksandar Fotić (Beograd), Vladan Gavrilović (Novi Sad), Alojz Ivanišević (Wien),

Egidio Ivetić (Padova), Husnija Kamberović (Sarajevo), Karl Kaser (Graz),

Irina Ognyanova (Sofija), Géza Pálffy (Budapest), Ioan-Aurel Pop (Cluj),

Nade Proeva (Skopje), Alexios Savvides (Kalamata), Vlada Stanković (Beograd), Ludwig Steindorff (Kiel), Peter Štih (Ljubljana)

\section{Izvršna urednica za tuzemnu i inozemnu razmjenu / Executive Editor for Publications Exchange \\ Kristina Milković}

Tajnik uredništva / Editorial Board Assistant
Dejan Zadro

Adresa uredništva/Editorial Board address

Zavod za hrvatsku povijest, Filozofski fakultet Zagreb, Ivana Lučića 3, HR-10 000, Zagreb

Tel. ++385 (0)1 6120 150, 6120 158, faks ++385 (0)1 6156879

Časopis izlazi jedanput godišnje / The Journal is published once a year

Časopis je u digitalnom obliku dostupan na / The Journal in digital form is accessible at Portal znanstvenih časopisa Republike Hrvatske „Hrčak“ http://hrcak.srce.hr/radovi-zhp

Financijska potpora za tisak časopisa / The Journal is published with the support by

Ministarstvo znanosti, obrazovanja i športa Republike Hrvatske

Časopis je indeksiran u sljedećim bazama / The Journal is indexed in the following databases:

Directory of Open Access Journals, EBSCO, SCOPUS, ERIH PLUS, Emerging Sources Citation Index - Web of Science 


\section{Naslovna stranica}

Iva Mandić

Grafičko oblikovanje i računalni slog

Marko Maraković

\section{Lektura}

Samanta Paronić (hrvatski / Croatian)

Dražen Nemet (engleski / English)

Tisak

Tiskara Zelina d.d., Sveti Ivan Zelina

Naklada

250 primjeraka

Časopis je u digitalnom obliku dostupan na Portalu znanstvenih časopisa Republike Hrvatske ,Hrčak" http://hrcak.srce.hr/radovi-zhp

The Journal is accessible in digital form at the Hrcak - Portal of scientific journals of Croatia http://hrcak.srce.hr/radovi-zhp 


\section{RADOVI 48}

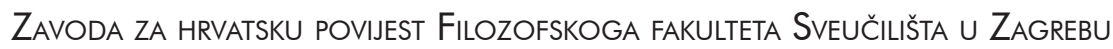

